https://doi.org/10.35339/msz.2019.82.01.07

UDC 616.1/.4-036.12:612.39

A. Shalimova, A. Isayeva, M. Vovchenko,

L. Rieznik, O. Buriakovska, N. Emelyanova

Government Institution "L.T. Malaya Therapy National Institute of the National Academy
of Medical Sciences of Ukraine», Kharkiv

\title{
EATING BEHAVIORAL REACTIONS OF PATIENTS WITH CHRONIC NON-COMMUNICABLE DISEASES AND ITS CORRECTION
}

The peculiarities of the eating behavioral reactions of patients with chronic non-communicable diseases and the effect of group and individual therapy on them were evaluated. It was established, that with a tendency to positive changes in eating behavior, conducting both group and individual therapy for 1 year did not significantly change its indicators such as daily consumption of salt, vegetables and fruits, smoking and alcohol consumption, which confirms the complexity of the impact on the specified risk factor for the development and progression of chronic non-communicable diseases.

Keywords: eating behavior, chronic non-communicable diseases, group therapy, individual therapy.

\section{Introduction}

Eating behavior is a set of human behavioral actions that are an integral part of the lifestyle aimed at choosing food, the conditions and mode of eating for satisfaction of physiological, psychological and socio-economic needs [1-4].

Eating behavior is formed under the influence of family, national, psychophysiological features, socio-cultural and ethical values, features of metabolism in the body and health. It depends on the interaction of the feeling of hunger and satiety, appetite, the ratio of motivational and emotional components [5-8].

Currently, eating behavior is considered not only as a component of lifestyle aimed at satisfying physiological and psychological needs, which includes: choice, methods of cooking and eating, conditions and diet, but also as a significant additional risk factor for the development of chronic non-communicable diseases [4, 9-12]. It is believed, that the study of the features of eating behavior and the development of programs for its modification will improve the primary and secondary prevention of chronic non-communicable diseases $[4,7]$.

Taking into account the role of eating behavior in the development and progression of chronic non-communicable diseases, the aim of the study was to assess the features of food behavioral reactions in patients with chronic noncommunicable diseases and the impact on them of group and individual therapy.

\section{Materials and methods}

The study included patients with high and very high cardiovascular risk. The inclusion criteria for the study were: signed informed consent; high and very high cardiovascular risk; the desire and opportunity to continue the drug therapy that was chosen in the hospital; absence of side effects associated with medication therapy; absence of significant violations of the cognitive function; high level of adherence to medical treatment. Criteria for exclusion from the study were: oncological diseases; insulin-dependent diabetes mellitus;

(C) A. Shalimova, A. Isayeva, M. Vovchenko et al., 2019 
thyroid dysfunction; heart failure IV functional class; depressive disorders; disturbance of the locomotor apparatus, which significantly limits the physical activity; planned surgical intervention; the impossibility for any reason to continue the medical therapy prescribed in hospital; acute inflammatory processes.

Patients were divided into groups by randomization with sealed envelopes: 75 patients undergone group training in Schools of Health and 75 patients undergone individual training. Total duration of study in groups was 1 year. Groups did not differ in age and gender ratios.

Group training consisted of 9 classes with frequency 1 time per month (duration was 1 hour). Each session consisted of 4 lectures (15 minutes each) and was devoted to one of the most common chronic non-infectious diseases: coronary artery disease, arterial hypertension, diabetes mellitus, diseases of the musculoskeletal system, thyroid gland, age-associated lesions of the central nervous system. Particular attention was paid to the main risk factors of the disease and methods for their correction. Classes were conducted by a cardiologist, dietician and instructor of physical education. At the beginning of the cycle, patients were given methodical materials and an individual diary. After each lesson, patients received tasks that they performed in an individual diary.

Patients from an individual group also visited the clinic once a month. There were 9 visits in total. The cardiologist, endocrinologist, dietician, dentist and instructor of medical physical education communicated with the patient in turn (one by one). The duration of the individual consultation with each specialist was 15 minutes. Patients also received tasks that were performed in an individual diary.

Eating behavior was evaluated using a questionnaire developed by department staff. The daily consumption of kitchen salt (less than or equal to $5 \mathrm{~g}$ per day), vegetables and fruits (less than or equal to $500 \mathrm{~g}$ per day), the smoking factor (in the past and now), as well as the use of alcohol were determined. These components of eating behavior were evaluated at the beginning of the study, as well as their changes under the influence of group and individual therapy.

\section{Results and their discussion}

Evaluation of attitudes towards smoking showed that the majority of participants at the beginning of group therapy ( $92 \%$ of respondents) to the question in the questionnaire «Do you smoke?» answered «No», 2,7 \% of respondents said that they smoke, and another 5,3\% smoked in the past, but left out. At the same time, the prevalence of smoking among women and men was not significant differences.

Among the participants in individual therapy, the overwhelming majority of respondents denied the fact of smoking $(90,7 \%), 4,0 \%$ noted that they smoke, and another 5,3\% smoked in the past, but left out. As among the participants of group therapy, in this group there were no significant gender differences in the prevalence of smoking and the number of cigarettes that the respondents smoked during the day.

Analysis of another component of food behavioral reactions, namely, the moderate strong alcohol consumption, showed that the absolute majority of respondents from both group and individual therapy (94,7 and 92,0\% respectively) denied alcohol consumption both now and in the past. At the same time, $82 \%$ of respondents in group therapy and $78 \%$ of participants in individual therapy confirmed the periodic use of low-alcohol beverages (beer and dry wine).

One component of the assessment of eating behavior was the analysis of daily consumption of vegetables. It should be noted that according to the questionnaire, only $24 \%$ of the respondents of group therapy (before the start of therapy) responded that they consumed more than $500 \mathrm{~g}$ of vegetables per day, whereas in most patients in the daily diet, vegetables were present in a smaller number. A similar distribution of respondents regarding the amount of vegetables in the diet was also characteristic for the group of individual therapy (only $20 \%$ of respondents noted that they consume more than $500 \mathrm{~g}$ of vegetables per day). Gender analysis of the presence of vegetables in the daily ration showed that among respondents who received enough (more than $500 \mathrm{~g}$ of vegetables per day), the percentage of women was significantly higher than men ( 74 and $26 \%, p<0,05$ in patients with group therapy and 78 and $22 \%, p<0,05$ in the group of individual therapy).

Another component of the analysis of eating behavior was the assessment of patients' awareness of the amount of salt consumed. Among the participants in group therapy at the beginning of its implementation, only $29,3 \%$ of respondents noted that they are aware of the 
amount of salt consumed and are trying to limit their content to less than $5 \mathrm{~g}$ (incomplete teaspoon) in a daily ration. Similar data were noted at the beginning of individual therapy: according to the questionnaire, $33,3 \%$ of respondents restricted the salt content in the daily ration.

Analysis of both variants of therapy showed that the number of smokers did not change either among the participants in the group therapy or among the participants in the individual therapy.

Regarding the influence of both therapies on the correction of another component of behavioral food responses (alcohol consumption), it should be noted that the number of patients who denied the use of strong alcohol after the group therapy did not increase significantly from 94,7 to $96,0 \%$ ( $p>0,05$ ), and the number of such patients in the group of individual therapy unreliable increased from 92,0 to $94,7 \%(p>0,05)$. At the same time, in the group of patients with individual therapy, the number of people who confirmed the periodic use of low-alcohol beverages decreased (from 78 to $64 \%, p>0,05)$. Among respondents in group therapy, the percentage of patients who periodically used low-alcohol beverages did not change.

Analysis of daily consumption of vegetables after treatment showed that in patients with group therapy, the number of people who daily consumes more than $500 \mathrm{~g}$ of vegetables per day did not increase significantly from 24,0 to $29,3 \%$ $(p>0,05)$. When conducting individual therapy, the number of people who daily eat more than $500 \mathrm{~g}$ of vegetables per day has increased from 20 to $28 \%$, but it is unreliable $(\mathrm{p}>0,05)$, as in the first variant of therapy. It should be noted that in both groups of patients, among those who increased the content of vegetables in the diet, women were predominant $(72 \%$ of participants in group therapy and $78 \%$ of participants in individual therapy).

The assessment of the effect of the two therapeutic options on the awareness of patients about the amount of salt consumed showed that the number of patients, both group and individual therapy, limiting the amount of salt in the daily diet, tended to increase, but the difference in the rates before and after the therapy was not reliable: in patients with group therapy, the number of people who restricted the salt content to $5 \mathrm{~g}$ per day increased from 29,3 and $34,7 \%$, and in patients of individual therapy their number increased from 33,3 to $40,0 \%, p>0,05$. It should be noted gender differences in improving the awareness of patients about the amount of salt consumed: in both therapies, women (76\% in group therapy and $84 \%$ in individual therapy) dominated the diet for limiting daily salt intake.

Thus, despite the fact that the conduct of both group and individual therapy, did not significantly affect the change in dietary behavior of patients, but there was a tendency for its positive changes.

The insufficiency of changes in the components of eating behavior can be attributed to the fact that eating disorder relates to some of the most difficult in diagnostic and therapeutic aspects. Conducting group therapy, and even individual therapy for 1 year, was not sufficient to correct the disorder of eating behavior, as the impact on the psychological component of the formation of these disorders requires a lengthy program. Eating behavior is formed in early childhood, in the family, partly due to genetics, but to a greater extent depends on the sociocultural environment and the material state of man $[3,6,12]$. Therefore, changes can not be sudden, and medical methods of correction of metabolic disorders are more and more relevant, even for people with low and moderate development of cardiovascular complications.

The results can also be explained by the limitations associated with the research design. The questionnaire evaluated the following components of eating behavior, such as the consumption of kitchen salt, vegetables and fruits, the factor of smoking and the use of alcohol, in the absence of information about all dietary intakes of the daily diet, the number and multiplicity of meals, the way of cooking, food habits and stress.

\section{Conclusions}

In the presence of a tendency to positive changes in eating behavior, both group and individual therapy for 1 year did not significantly change such indicators as daily consumption of kitchen salt, vegetables and fruits, smoking and alcohol consumption, which confirms the complexity of the effect on the specified risk factor development and progression of chronic non-communicable diseases.

The prospect of the study is to find ways of a comprehensive and long-term impact on the formation of a proper dietary stereotype. 


\section{References}

1. Azagba S., Sharaf M.F. (2012). Eating behavior and obesity in Canada. J. Prim. Care Comm. Health, vol. 3 (1), pp. 57-64, PMID: 23804856.

2. Phillips C.M. (2013). Nutrigenetics and metabolic disease: current status and implications for personalized nutrition. Nutrients, vol. 5 (1), pp. 32-57, PMID: 23306188, PMCID: PMC3571637.

3. Sung J., Lee K., Song Y.M., Lee M.K., Lee D.H. (2010). Heritability of eating behavior assessed using the DEBQ (Dutch Eating Behavior Questionnaire) and weight-related traits: the Healthy Twin Study. Obesity (Silver Spring), vol. 18 (5), pp. 1000-1005, PMID: 19876000.

4. Yumuk V. (2015). European guidelines for obesity management in adults. European J. Obesity. Obesity Facts, vol. 8, pp. 407-412, PMID: 26641646, PMCID: PMC5644856.

5. Berner L.A., Arigo D., Mayer L.E., Sarwer D.B., Lowe M.R. (2015). Examination of central body fat deposition as a risk factor for loss-of-control eating. The American Journal of Clinical Nutrition, vol. 102 (4), pp. 736, PMID: 26354534, PMCID: PMC4588740.

6. Oliveira A., Maia B., Lopes C. (2014). Determinants of inadequate fruit and vegetable consumption amongst Portuguese adults. J. Hum. Nutr. Diet, vol. 27 (12), pp. 194-203, PMID: 23889074.

7. Schaumberg K., Anderson D. (2016). Dietary restraint and weight loss as risk factors for eating pathology. Eating Behaviors, vol. 23, pp. 97-103, PMID: 27611582.

8. Tackett B.P., Petrie T.A., Anderson C.M. (2016). The frequency of weigh-ins, weight intentionality and management, and eating among female collegiate athletes. Eating Behaviors, vol. 23, pp. 82-85, PMID: 27579968.

9. Lee H.A., Lee W.K., Kong K.A., Chang N., Ha E.H., Hong Y.S., Park H. (2011). The effect of eating behavior on being overweight or obese during preadolescence. J. Prev. Med. Public Health, vol. 44 (5), pp. 226-233, PMID: 22020188, PMCID: PMC3249260.

10. Martinez-Gonzalez M.A., Corella D., Salas-Salvado J., Ros E., Covas M.I., Fiol M. et al. (2012). Cohort profile: design and methods of the PREDIMED study. Int. J. Epidemiol., vol. 41, pp. 377-385, PMID: 21172932.

11. Mottillo S., Filion K.B., Genest J., Joseph L., Pilote L., Poirier P., Rinfret S., Schiffrin E.L., Eisenberg M.J. (2010). The metabolic syndrome and cardiovascular risk a systematic review and metaanalysis. J. Am. Coll. Cardiol., vol. 56 (14), pp. 1113-1132, PMID: 20863953.

12. Mumu S.J., Saleh F., Ara F., Afnan F., Ali L. (2014). Non-adherence to life-style modification and its factors among type 2 diabetic patients. Indian J. Public Health, vol. 58 (1), pp. 40-44, PMID: 24748356.

\section{А.С. Шалимова, А.С. Исаева, М.Н. Вовченко, Л.А. Резник, А.А. Буряковская, Н.Ю. Емельянова ПИЩЕВЫЕ ПОВЕДЕНЧЕСКИЕ РЕАКЦИИ ПАЦИЕНТОВ С ХРОНИЧЕСКИМИ НЕИНФЕКЦИОННЫМИ ЗАБОЛЕВАНИЯМИ И ИХ КОРРЕКЦИЯ}

Оценивали особенности пищевых поведенческих реакций пациентов с хроническими неинфекционными заболеваниями и влияние на них групповой и индивидуальной терапии. Установлено, что при тенденции к позитивным изменениям пищевого поведения проведение как групповой, так и индивидуальной терапии в течение 1 года достоверно не изменило такие его показатели, как суточное потребление поваренной соли, овощей и фруктов, курение и употребление алкоголя, что подтверждает сложность влияния на указанный фактор риска развития и прогрессирования хронических неинфекционных заболеваний.

Ключевые слова: пищзевое поведение, хронические неинфекционные заболевания, групповая терапия, индивидуальная терапия. 
А.С. Шалімова, Г.С. Ісаєва, М.М. Вовченко, Л.А. Рєзнік, О.О. Буряковська, Н.Ю. Смельянова ХАРЧОВІ ПОВЕДІНКОВІ РЕАКЦІЇ ПАЦІЕНТІВ ІЗ ХРОНІЧНИМИ НЕІНФЕКЦІЙНИМИ ЗАХВОРЮВАННЯМИ ТА ЇХНЯ КОРЕКЦІЯ

Оцінювали особливості харчових поведінкових реакцій пацієнтів із хронічними неінфекційними захворюваннями та вплив на них групової й індивідуальної терапії. Установлено, що за тенденції до позитивних змін харчової поведінки проведення як групової, так і індивідуальної терапії протягом 1 року достовірно не змінило такі її показники, як добове споживання кухонної солі, овочів та фруктів, паління і вживання алкоголю, що підтверджує складність впливу на зазначений фактор ризику розвитку і прогресування хронічних неінфекційних захворювань.

Ключові слова: харчова поведінка, хронічні неінфекційні захворювання, групова терапія, індивідуальна терапія.

Надійшла 25.03.19

\section{Відомості про авторів}

Шалімова Анна Сергіївна - доктор медичних наук, професор кафедри внутрішньої медицини № 1 Харківського національного медичного університету, провідний науковий співробітник відділу комплексного зниження ризику хронічних неінфекційних захворювань ДУ «Національний інститут терапії імені Л.Т. Малої АМН України», лікар-терапевт вищої кваліфікаційної категорії, лікар загальної практики - сімейної медицини вищої кваліфікаційної категорії.

Адреса: 61039, м. Харків, пр. Любові Малої, 2а, ДУ «Національний інститут терапії імені Л.Т. Малої АМН України».

Тел.: +38(067)934-69-75.

E-mail: anna.shalimova83@gmail.com.

ORCID: https://orcid.org/0000-0002-1016-0740.

Ісаєва Ганна Сергіївна - доктор медичних наук, завідувач відділу комплексного зниження ризику хронічних неінфекційних захворювань ДУ «Національний інститут терапії імені Л.Т. Малої АМН України».

Адреса: 61039, м. Харків, пр. Любові Малої, 2а, ДУ «Національний інститут терапії імені Л.Т. Малої АМН України».

Тел.: +38(050)400-65-50

E-mail: anna_isayeva_74@yahoo.co.uk.

ORCID: https://orcid.org/0000-0003-0515-6146.

Вовченко Марина Миколаївна - кандидат медичних наук, науковий співробітник відділу комплексного зниження ризику хронічних неінфекційних захворювань ДУ «Національний інститут терапії імені Л.Т. Малої АМН України».

Адреса: 61039, м. Харків, пр. Любові Малої, 2а, ДУ «Національний інститут терапії імені Л.Т. Малої АМН України».

Тел.: +38(050)572-84-67.

E-mail:mar.vovch@gmail.com.

ORCID: https://orcid.org/0000-0002-4704-4604.

Рєзнік Лариса Аркадіївна - кандидат медичних наук, старший науковий співробітник відділу комплексного зниження ризику хронічних неінфекційних захворювань ДУ «Національний інститут терапії імені Л.Т. Малої АМН України».

Адреса: 61039, м. Харків, пр. Любові Малої, 2а, ДУ «Національний інститут терапії імені Л.Т. Малої АМН України».

Тел.: +38(067)714-87-65.

E-mail: larisareznik@ukr.net.

ORCID: https://orcid.org/0000-0001-5200-3447. 
Буряковська Олена Олександрівна - молодший науковий співробітник відділу комплексного зниження ризику хронічних неінфекційних захворювань ДУ «Національний інститут терапії ім. Л.Т. Малої НАМН України».

Адреса: 61039, м. Харків, пр. Любові Малої, 2а, ДУ «Національний інститут терапії імені Л.Т. Малої НАМН України».

Тел.: +38(095)243-13-33.

E-mail: alena.tbtch@gmail.com.

ORCID: https://orcid.org/0000-0002-6488-3426.

Ємельянова Наталія Юрївна - лікар-стоматолог, кандидат медичних наук, науковий співробітник відділу комплексного зниження ризику хронічних неінфекційних захворювань ДУ «Національний інститут терапії ім. Л.Т. Малої НАМН України».

Адреса: 61039, м. Харків, пр. Любові Малої, 2а, ДУ «Національний інститут терапії імені Л.Т. Малої НАМН України».

Тел.: +38(097)834-24-29.

E-mail:natadenta@gmail.com.

ORCID: https://orcid.org/0000-0001-6089-6206. 